\title{
Islamic Monetary Instruments Contribution to Economic Growth: Literature Study
}

\author{
Andri Soemitra ${ }^{1}$ Rifki Ismal ${ }^{2} \mathrm{Amin} \mathrm{Al} \mathrm{Jawi}{ }^{3} \mathrm{Afriza}^{4} \mathrm{Juliana}_{\text {Nasution }}{ }^{5} \mathrm{M}$. Indra Mulia Nasution ${ }^{6}$ \\ 1,3,4,5,6 Universitas Islam Negeri Sumatera Utara Medan \\ ${ }^{2}$ Sekolah Tinggi Ilmu Ekonomi Islam Tazkia Bogor \\ Email Corespondent :juliananasution@uinsu.com
}

\begin{abstract}
In Islamic economics, the monetary sector and the real sector must be able to go side by side. Even the monetary sector must follow developments for the real sector. The goal of Islamic economics is the creation of economic justice through equitable distribution of income, one of which is seen from the growth of the real sector, which is a representation of the level of productivity and welfare of the community. This is directly related to the business world. Therefore, when the level of community productivity increases, it will aggregately affect economic growth. On the other hand, one of the monetary instruments in Islamic economics is Islamic banking. This means that the increasing performance of Islamic banking must be in line with the increase of the real sector. The purpose of this study is to analyze the contribution of increasing Islamic banking performance to economic growth through a literature study related to a qualitative approach, where the collected literature is analyzed by content analysis and the data is triangulated to make a conclusion. The findings of this study indicate that Islamic monetary instruments in the Islamic banking case contribute to economic growth through an increase from the real sector.
\end{abstract}

Keywords : Islamic monetary instruments, economic growth, Islamic banking, real sector

\begin{abstract}
Abstrak:Dalam ekonomi Islam, sektor moneter dan sektor riil harus dapat berjalan beriringan. Bahkan sektor moneter harus mengikuti perkebangan sektor riil. Tujuan ekonomi islam adalah terciptanya keadilan ekonomi melalui pemertaan pendaoatan yang salah satunya dilihat dari pertumbuhan sektor riil yang merupakan representasi dari tingkat produktivitas dan kesjahteraan masyarakat. Hal ini berkaitan langsung dengan dunia bisnis. Oleh karena itu, ketika tingkat produktivitas masyarakat meningkat, secara agregat akan memengaruhi pertumbuhan ekonomi. Di sisi lain, salah satu instrument moneter dalam ekonomi syariah adalah perbankan syariah. Artinya, peningkatan kinerja perbankan syariah harus sejalan dengan peningkatan sektor riil. Tujuan dari penelitian ini adalah untuk menganalisis kontribusi peningkatan kinera perbankan syariah terhadap pertumbuhan ekonomi melalui studi literatur yang berkaitan dengan pendekatan kualittatif, dimana literature yang terkumpul dianalisis dengan konten analisis dan data ditriangulasi untuk dijadikan kesimpulan. Temuan penelitian ini menunukan bahwa instrumen moneter syariah dalam hal perbankan syariah berkontribusi terhadap pertumbuhan ekonomi melalui peningkatan dari sektor riil.
\end{abstract}

Keywords : Instrumen moneter syariah, Pertumbuhan ekonomi, Perbankan syariah, Sektor riil. 


\section{INTRODUCTION}

The economic stability of a country is largely determined by the precise fiscal and monetary policies that are implemented. The two policies are interrelated, support and complement each other. If fiscal policy is carried out by regulating state revenues and expenditures to maintain economic stability, then monetary policy is carried out by regulating currency value stability through controlling the money supply in the community which also aims to maintain economic stability. Both fiscal and monetary policies are ultimately carried out to increase economic growth, one of the main indicators of which is income distribution to create people's welfare.

In the context of monetary policy, an interesting issue today is the issue of Islamic monetary instruments, one of which is marked by the increasing performance of Islamic banking. Why is it interesting? It is because the vision of Islamic economics is to create justice through the creation of an even distribution of income in the community which is the main indicator of economic growth. That is why in Islamic economics, the monetary sector and the real sector must go hand in hand. As a matter of fact the monetary sector must follow developments in the real sector (Ismal, 2011). Why? It is because the real sector is a representation of the level of productivity of a country's society in creating goods and services. When the productivity level of the people of a country increases, in aggregate it will have an effect on increasing national income and economic growth. Moreover, the real sector is also arepresentation of the level of welfare of the people of a country because it is directly related to the business world(Titman, S \& Warga, 1989).

The question then is, is it true that in reality the increasing performance of
Islamic banking simultaneously with increasing growth in the real sector, which is followed by an increase in community productivity, will ultimately increase national income and economic growth? Therefore, researchers thought that it is important to conduct a literature research that focuses on the contribution of Islamic monetary instruments, in this case Islamic banking to economic growth through the growth of the real sector. The research is considered important so that it becomes an evaluation material for Islamic banking on the vision and goals of the Islamic economy itself.

\section{LITERATURE REVIEW}

\section{Islamic Bank}

Islamic Bank is an intermediary institution that collects funds from the public in the form of savings/giro/deposits that are invested in the real sector of the economy that is permitted by sharia. In terms of functions, Islamic and conventional banks have some similarities, especially in fundraising and investment. However, the two are very different in their financing instruments. Islamic banks develop interest-free financing instruments based on two principles, namely profit- and loss-sharing and additional margin (markup margin). While conventional banks adopt loans (loans) based on interest (interest/usury) (Ibrahim, 2015)

In the Law of the Republic of Indonesia Number 21 of 2008, the definition of Islamic Bank is a bank that carries out business activities based on sharia principles, or Islamic legal principles regulated in the fatwa of the Indonesian Ulama Council, such as the principles of justice and balance ('adl wa tawazun), benefit (maslahah), universalism (natural), and does not contain gharar, maysir, usury, injustice and unlawful objects. In addition, the Islamic Banking 
Law also mandates Islamic banks to carry out social functions by carrying out functions such as baitul maal institutions, namely receiving funds from zakat, infaq, alms, grants, or other social funds and channeling them to waqf managers (nazhir) as desired waqf (wakif). Meanwhile, the purpose of Islamic banking is to support the implementation of national development in order to improve justice, togetherness, and equitable distribution of people's welfare (Nastiti, N.D., \& Kasri, 2019). The circulation of money through financial institutions that flows into the real sector will drive the economy. Islamic banking is ideally aimed at realizing economic benefits and being a driving force for the real sector economy. The objectives of Islamic banking will be achieved if Islamic banks channel financing to productive sectors that can improve the economy in real terms so that new business sectors will be created and job opportunities will be increased which in turn will encourage the increased income and community welfare.

\section{Economic Growth}

Economic growth is a condition for the development of Gross Domestic Product (GDP) which reflects the growth of output per capita and the increase in people's living standards. Economic growth is a process in the economy that causes an increase in goods and services through a continuous increase in productive capacity in the economy and an increase in theprosperity of the people in a country. In another definition, the term economic growth is used to describe the progress or development of the economy in a country. That is, economic growth is defined as the development of economic activities that take place in a country from time to time which causes real national income to increase(Ghura, H., Li, X. \& Harraf, 2017).
Furthermore, there are three aspects that need to be considered related to economic growth, namely: (i) process, (ii) output per capita, and (iii) long term. This means that economic growth is a dynamic process that describes economic development from time to time. Output per capita relates to aspects of total output and population. Then the long term shows the tendency of changes in the economy in a certain period of time driven by internal changes in the economy. Many factors affect the economic growth of a country, both internal and external factors(Awdeh, A. \& Hamadi, 2019).

Economic growth is the most important part of economic policy in any country with any economic system. Because economic growth will lead to greater economic opportunities and equity for the community. In the study of Islamic economics, the issue of economic growth has been a concern since the beginning. Allah says in the Qur'an surah Hud verse 61, which means: "He who has made you from clay and made you prosperous". In this verse, Allah made humans the prospe of the earth. The 'Prosperity of the Earth' is of course human prosperity as a filler of the earth itself, because the purpose of economic growth is to equalize income to create community welfare. Even though currently many Muslim countries are experiencing economic backwardness, it is more due to more complex problems. As a religion, Islam teaches the concept of working and building on the basis of religious teachings(Y, 2019).

Economic growth in Islamic economics covers a wider side, not only growth and progress in material aspects but also human spiritual aspects. In Islamic economics individual behaviour must be based on ethics, values and morals. So that Islamic rational man does not only satisfy materially, but also has to pay attention to his spiritual satisfaction. It is very 
important to maintain a balance of material and spiritual growth in the concept of economic growth with an Islamic perspective (M. Bashir, 2002). Islam teaches that benefits in economic growth can be realized if you consider in a balanced way the ownership and consumption of material goods and services and balance spiritual needs.

Islam has its own characteristics in terms of its economic growth goals(A. H. $\mathrm{M}$, 1987), namely: Comprehensive (assyumuliyah). Which means that economic growth is not just a material issue, but has a more universal and comprehensive purpose. That is, economic growth must be oriented towards goals and values(Sexton M, 2006). Material, moral, economic, social spiritual and fiscal aspects cannot be separated. The happiness to be achieved is not only material happiness and prosperity in this world, but also in the hereafter(M. $H, 2016)$. Therefore, physical development must be accompanied by human development. Balanced (tawazun). That economic growth is not only oriented tocreate additional production, but is aimed at the principle of distributional justice. Therefore, Islam does not accept the policy of urban growth by ignoring the countryside, industry that ignores agriculture or by concentrating on accelerating the development of certain programs by ignoring public facilities and other basic infrastructure. Justice ('adalah). That economic growth must be accompanied by distributive justice. That wealth should not only circulate to a few people so that welfare can be evenly distributed in the midst of society. Responsible (mas'uliyyah). That economic growth must be sustainable. That is, it must pay attention to ecological factors by not exploiting all existing resources without paying attention to their sustainability. Because individual freedom to enjoy worldly pleasures is not given absolutely without limits. This freedom is limited by various rules that indicate the guarantee of happiness for all members of society, even the environment. Focus on humans (ghayatuha al-insan). That Islam expands the scope of the object of development from the physical environment to humans. Islam is very concerned about the problem of economic development, but still places it on a larger development problem, namely the development of mankind. The main function of Islam is to guide people on the right path and the right direction. All aspects related to economic development must be integrated with the development of humanity as a whole.

\section{METHODOLOGY RESEARCH}

This research is a type of qualitative research with a literature study approach. The literature study was conducted by collecting journal articles in accordance with the research objectives, namely the contribution of Islamic monetary instruments in this case Islamic banking to economic growth and then carried out an analysis (content analysis). Content analysis is an analytical method by trying to find out the content and intent of a text to produce an objective description. The data needed in research can be obtained from library sources or documents sourced from journal articles that are adapted to the research theme. Content analysis is research that is indepth discussion of the contents of a written or printed information, or a research technique to make inferences that can be imitated and valid data by taking into account the context.

The content analysis technique is carried out through three main stages. First, by data reduction, where the data obtained from journal articles are reduced, summarized and selected important points, then the suitability of the research objectives to be studied is seen to make it easier to understand. Second, by displaying the data, that is, by describing the information obtained as a result of data 
reduction which allows for data conclusions to be drawn in accordance with the intended research. Third, by drawing conclusions where the researchers look for the meaning of the data collected and then draws more basic conclusions in accordance with the intended research.

\section{RESEARCH RESULTS}

\section{Hasil}

Based on the search results of relevant journal research with the help of reputable journal indexing engines and sci-hub, the authors found 10 English-language journal publications and 11 Indonesian-language journal publications. Then the researcher analyzed the material from each of these journals based on the research objectives by taking several studies that had material specifications that aimed to answer this research.

The classification of the first journal articles discusses the role of banking in economic growth in Indonesia: Islamic banks versus conventional banks conducted by Iwan Setiawan (2020). This research specifically examines the contribution of Islamic banks through the role of financing to economic growth, the contribution of conventional banks through the role ofcredit to economic growth. The results of this study indicate that conventional bank credit and Islamic bank financing have a significant effect on economic growth in the country. The increase in credit and financing has a positive effect on economic growth. Every $1 \%$ increase in conventional bank credit results in an increase in economic growth of $0.322 \%$. Then every $1 \%$ increase in Islamic bank financing results in an increase in economic growth of $0.126 \%$. The coefficient value shows that the change is not too large, is inelastic, but the effect is significant. Any increase in the value of credit and financing in the domestic banking industry has the potential to result in economic growth.

Then Ali Rama (2013) conducting research aimed at testing and knowing empirically the dynamic relationship between the development of Islamic banking, capital markets, trade, inflation and economic growth in Indonesia. The researcher reveals that there is a bidirectional causality between the development of Islamic banking and economic growth. This finding is in line with the hypothesis of "the feedback hypothesis" or "the bidirectional causality view". These empirical results prove that the growth of Islamic banking in Indonesia can encourage high economic expansion through forms of sharia-compliant products and services. Of course, this is in line with the character of Islamic banking itself which is very pro and emphasizes the real economic sector. If Islamic banking financial institutions respond effectively to increase demand as a result of high economic growth, these changes will then stimulate higher economic performance. The development of the banking sector and the economy will ultimately need each other and their relationship will encourage bi-directional causality. Through the results of this study, Islamic banking has effectively played its role as an intermediary institution that facilitates the mobilization of capital from surplus units to deficit units, economic sectors that have excess capital to economic sectors that need financing. Therefore, we can say that the policy of the Central Bank of Indonesia and other relevant authorities to develop a comprehensive Islamic financial system in Indonesia is considered effective, as long as the development of the financial sector and economic growth/real sector are closely related. This study also indicates that the improvement of Islamic banking infrastructure in Indonesia will provide 
benefits to economic development and this is important in the long term for the development of people's welfare.

Furthermore, research conducted by Raditya Sukmana and Salina H. Kassim (2010)which discusses the Role of Islamic Banks in the Monetary Transmission Process. In particular, this study analyzes the relevance of Islamic bank financing and savings in channeling the effects of monetary policy to the real economy. Theoretically, bank lending channels exist when the impact of monetary policy works through bank deposits, bank loans and then on to the real economy. Given the fact that there is a dual banking system, it is interesting time to see if Islamic banks are also able to react in the same way as conventional banks after the central bank imposes certain monetary policies. Therefore, this study intends to contribute in terms of offering a more detailed aspect of monetary policy strategy, especially in the context of the dual banking system. The results show that Islamic banks play an important role in the process of transmitting monetary policy, because of the effective role of Islamic banks in transmitting the effects of monetary policy to the real economy. It is therefore important for policy makers to take into account Islamic banks in the design and implementation of monetary policy.

The next research is the research of Emy Widyastuti and Yusvita Nena Arinta (2020)which discusses the contribution of Islamic banking in Indonesia's economic growth, in particular examining the effect of consumption financing on Indonesia's economic growth which is clustered according to use and business category consisting of short-term and long-term financing. The researchers assert that in the short and long term, consumption financing has a statistically negative and significant effect on Indonesia's economic growth. Indonesian Islamic banking financing by use and business category consisting of working capital financing, investment financing and consumption financing has contributed to the dynamics of Indonesia's economic growth. The increase of consumption financing in the short and long term will reduce economic growth, so that in order to contribute to Indonesia's economic growth, Islamic banking is expected to further optimize other types of financing that are more productive so that they can contribute to Indonesia's economic growth.

Then Amel Boukhatem \& Fatma Ben Moussa (2018)conducted research on the relationship between Islamic financial institutions and economic growth. Specifically assessing empirically the influence of Islamic bank loans on economic growth in 13 countries in the MENA region. This study explains that the development of the financial system encourages economic growth. This finding confirms similar conclusions from various studies on the importance of deepening the financial sector to promote economic growth. In addition, the development of Islamic finance (as measured by loans issued by Islamic banks) is positively correlated with economic growth. Therefore, the government boosts economic growth through the development of Islamic banking by implementing laws, regulations, and adequate support for infrastructure.

In the context of Islamic banking products, research conducted by Selim (2020)discusses istisna-based monetary and its effectiveness in achieving full employment and price stability. This study examines the exploration of istisna' as a monetary policy tool and examines its effectiveness in achieving full employment opportunities and price stability and examines its effect on macroeconomic variables. The effectiveness and impact of istisna-based monetary policy is examined 
using aggregate output and aggregate expenditure models embedded with Islamic economic principles, including the function of zakat. In the study, the researcher explains that istisna'-based monetary policy not only meets the requirements of Islamic law as an accepted model of Islamic financing, but also has the capacity to revolutionize financing of critical infrastructure and large government projects without accumulating debt and deficits. Because many governments try to finance infrastructure and large projects by borrowing funds at interest but unfortunately end up with huge public debts and chronic budget deficits without much infrastructure improvement. In istisna'a-based monetary policy, infrastructure and large projects are considered assets, and such assets generate income that will flow to the central bank as part of an interest-free contractionary monetary policy. Doing so will reduce government spending on these projects which in the end, the government will have more funds available to be spent in other important sectors, such as education, training, research, health, and others.

Then Irawan and Zulia Almaida Siregar (2019)which examines the Influence of Sharia Stocks, Sukuk and Sharia Mutual Funds on Indonesia's Economic Growth. In the study, it was stated that the growth can be seen from the indexed shares in 2012 of Rp1,67.004.23 billion, then in 2017 of Rp2,288.015.67 billion, meaning there has been a significant growth for 6 (six) years. Likewise, the development of sharia shares indexed in the Indonesian Sharia Stock Index (ISSI) also experienced significant growth. This can be seen from the development in 2012 of IDR 2,451,334.37 billion and in 2017 of IDR 3,704,543.09 billion.

Furthermore, Try Roedyhantoro research (2018). This study examines the Effect of Conventional Monetary
Instruments and Islamic Monetary Instruments on Gross Domestic Product (GDP). In this study it was found that Islamic monetary instruments have a significant influence on GDP. The question is, which of the conventional monetary instruments with Islamic monetary instruments has an influence. Researchers in this journal article explain that there is a relationship between conventional monetary instruments and Islamic monetary instruments with the variables of Bank Indonesia Certificates (BIC) and Reverse Repo of Government Securities for conventional instruments, as well as Bank Indonesia Sharia Certificates (BISC) and Reverse Repo of State Sharia Securities for instruments sharia monetary, the following conclusions are drawn:

1. BIC has a significant positive effect on GDP and shocks GDP for up to 18 months, and contributes $14.24 \%$ of the variance decomposition results. Meanwhile, Reverse Repo of Government Securities does not have a significant effect on GDP;

2. Both BISC and Reverse Repo of State Sharia Securities have no significant effect on GDP.

\section{DISCUSSION}

\section{The Relationship and Role of Islamic Banking on Economic Growth}

Economic growth in a country cannot be separated from the role of banking financing, because banking financing is one of the important instruments in monetary policy in a country. The relationship between banking performance and economic growth is certainly very close, because the development of the financial sector affects economic growth, and vice versa. If the financial sector experiences good growth, there will be more sources of financing that can be allocated to productive economic sectors, 
which in turn will increase community productivity in supporting economic growth.

Islamic banking and conventional banking are functionally similar in their effect on the economic growth of a country, especially in the function of financing to the public. However, the two are different in their instruments, if Islamic banks develop interest-free financing instruments based on two principles, namely profit- and loss-sharing and additional margin (mark-up margin). So, conventional banks adopt loans (loans) based on interest (interest/usury).

The use of the main sharia contracts, especially the use of a profit and loss sharing system, will ensure the distribution of wealth and income in line with the real sector being financed. This condition will certainly encourage the real sector to continue to grow and develop in accordance with the targeted expectations. Good economic growth will continue to push the pace of productivity and business opportunities to increase. Such an economic rate will automatically accelerate economic growth for the better from time to time.

On the other hand, Islamic banking also plays at least four important roles, namely: encouraging financing, stimulating savings, increasing financial stability, and contributing to financing projects in a Shariah-compliant manner. First, maximum financing will encourage the movement of the real sector economy and stimulate economic growth. Capital flows based on sharia contracts will flow to productive businesses that have underlying assets or underlying transactions. This situation is positive for efforts to improve welfare, especially moving the economic sector. Second, the income earned by business actors that are not used up in the consumption and production process will flow to the Islamic financial institution sector through savings schemes based on wadiah and mudharabah contracts. The flow of savings into the financial institution sector will reduce the burden of inflation due to the large amount of cash held by the public. On the other hand, money that goes to Islamic financial institutions will circulate to productive financing sectors. Third, the flow of money circulating in the community in sufficient quantities as well as the demand for financing flowing to the productive, nonspeculative sectors will ensure the stability of the financial system. Islam is very concerned about the use of money not to flow into speculative sectors which will only inflate money to levels that can cause a financial crisis in the economy. Fourth, Islamic financial institutions that are required to operate based on sharia contracts will certainly enter productive financing projects in various schemes, such as business cooperation, leasing, and selling and buying.

\section{The Relationship between Monetary Policy and Economic Growth}

There are 2 (two) types of monetary policy. First, expansionary monetary policy or the so-called loose monetary policy which aims to increase the money supply in order to stimulate a sluggish economy by increasing people's purchasing power. Second, contractionary monetary policy or the so-called tight monetary policy which aims to reduce the money supply in order to reduce inflation. Both types of monetary policy are certainly closely related to the economic growth of a country. Because the monetary policy carried out by the central bank in monetary control is in an effort to create stable economic conditions in a country, and economic growth in a country will not be achieved without the creation of stability in the economy.

In the context of Indonesia and the majority of Muslim countries in the world, 
the monetary system applied is a dual monetary system, namely the monetary system side by side between conventional and sharia monetary systems. The conventional monetary system uses an interest element while the sharia monetary system uses profit sharing and additional margin elements. The Islamic monetary system does not use the element of interest as in the conventional monetary system because interest in Islam is prohibited. The interesting thing is that Islamic monetary policy is a representation of the real sector, so there should be no dichotomy between the monetary sector and the real sector because essentially these two sectors must be interrelated and run in balance. This means that the financial sector cannot develop faster and larger than the real sector itself.

Of course this is in line with the vision of Islamic banking as a sub-system of the Islamic economy. The vision of Islamic economics is to create justice through the creation of an even distribution of income in the community which is the main indicator of economic growth. That is why in Islamic economics, the monetary sector and the real sector must go hand in hand. On top of that the monetary sector must follow developments in the real sector. The real sector is a representation of the productivity level of a country's society in creating goods and services. When the productivity level of the people of a country increases, in aggregate it will have an effect on increasing national income and economic growth. Moreover, the real sector is also a representation of the level of welfare of the people of a country because it is directly related to the business world.

What is special about Islamic monetary policy is that in Islamic economics there are a number of main rules that must be obeyed. Islamic monetary policy requires Islamic financial institutions to avoid ribawi transactions and other prohibited transactions such as acts of speculation. The prohibition of usury transactions and speculation in a monetary context will ensure that money flows into the real sector. In the Islamic monetary perspective, the financial market sector is placed as a supporter and supplier of funds to flow and become the moving capital of the productive sector. This indicates that in the perspective of Islamic policy the monetary sector and the productive sector are not in an equal position. Islam places the position of the financial market as a supporting sector that encourages economic growth in the goods and services sector through a capital supply scheme so that the real productive sector can expand the production of goods and services in the real sector.

Islamic finance schemes in Islamic monetary policy instruments ensure that various productive transaction mechanisms involve the existence of goods and services and there is a balance between risk and income. Islamic monetary policy instruments are issued through a sharia contract scheme so that money can flow from the financial market sector to the productive sector by using buying and selling transactions that require the production of goods, rent, and wages involving services from productive and halal goods, as well as good business cooperation. In the form of capital cooperation and works that also involve productive and halal goods and services. The entire mechanism for issuing Islamic monetary instruments ensures that Islamic finance is always closely linked to the real sector of productive goods and services.

Restrictions on Islamic monetary instruments so that they are not involved in usury schemes and speculation are also a strong guide so that finances are not involved in the financial sector which causes bubbles in the economy. Economic 
growth that is based on interest instruments and speculation is vulnerable to false growth because the increase in money is not followed by an increase in the production of goods and services in the real sector. As a result, if there is a failure in the financial sector that operates without underlying assets on which to rely on economic growth, the condition will trigger a financial crisis that will disrupt the economy not only on a national scale, but also globally.

\section{CLOSING}

An interesting issue in current monetary policy discussions is the existence of Islamic monetary instruments, one of which is marked by the increasing performance of Islamic banking. As we know that the vision of Islamic banking as a sub-system of the Islamic economy is to create justice through the creation of an even distribution of income in the community and become the main indicator of economic growth. That is why in Islamic economics, the monetary sector and the real sector must go hand in hand. Besides, the monetary sector must follow will maintain a solution to provide a monetary policy that is not only more stable, but developments in the real sector. Why? It is because the real sector is a representation of the level of community productivity in creating goods and services. When the level of community productivity increases, in aggregate it will have an effect on increasing national income and economic growth, which in turn becomes a representation of the level of community welfare because it is directly related to the business world.

After doing the research using a literature study approach, by collecting relevant journal articles, then analyzed (content analysis) to produce an objective description according to the research objectives, then it was found that the majority of the relevant research shows that Islamic monetary instruments in this case Islamic banking contribute to economic growth by increasing the real sector. The contribution of Islamic monetary is certainly still not felt optimally considering the small market share of the Islamic finance industry, both nationally and globally. However, the huge idea of implementing monetary policy by issuing sharia monetary instruments that ensure that money flows accompanied by the production of goods and services contributes more to economic growth both materially and spiritually. 


\section{REFERENSI}

A. H. M, S. (1987). Economic development in Islam. International Journal of Economics, Management and Accounting.

Amel Boukhatem dan Fatma Ben Moussa. (2018). The Effect of Islamic Banks on GDP Growth: Some Evidence from Selected MENA Countries. Borsa Istanbul Review, 231-247. https://doi.org/10.1016/j.bir.2017.11.004

Awdeh, A. \& Hamadi, H. (2019). Factors hindering economic development: evidence from the MENA countries. International Journal of Emerging Markets, Vol. 14 No, 281-299. https://doi.org/10.1108/IJoEM-12-2017-0555

Ghura, H., Li, X. \& Harraf, A. (2017). Moderating relationship of institutions for opportunity entrepreneurship and economic development: Literature review and proposed conceptual framework. Vol. 13 No, 350-374. https://doi.org/10.1108/WJEMSD-06-2017-0031

Ibrahim, M. H. (2015). Issues in Islamic banking and finance: Islamic banks, Shari'ahcompliant investment and Sukuk. Pacific-Basin Finance Journal. https://doi.org/10.1016/j.pacfin.2015.06.002

Irawan, I., \& Siregar, Z. A. (2019). Pengaruh Saham Syariah, Sukuk dan Reksadana Syariah Terhadap Pertumbuhan Ekonomi Indonesia. Jurnal Manajemen Dan Bisnis Islam. http://jurnal.uinsu.ac.id/index.php/tansiq/article/view/4848

Ismal, R. (2011). Central Bank Islamic Monetary Instruments: A Theoretical Approach. Studies in Economics and Finance, Vol. 28 Is.

M. Bashir, H. (2002). Property Rights, Institutions and Economic Development: An Islamic Perspective. Humanomics, Vol. 18 No, 75-91.

M. H, K. (2016). Islam and sustainable development. ICR Journal. ICR Journal, 7, 8-26.

M, S. (2020). Istisna'a Based Monetary Policy and Its Effectiveness in Achieving Full Employment And Price Stability. International Journal of Islamic and Middle Eastern Finance and Management. https://doi.org/10.1108/IMEFM-05-2019-0208

Nastiti, N.D., \& Kasri, R. A. (2019). The role of banking regulation in the development of Islamic banking financing in Indonesia. International Journal of Islamic and Middle Eastern Finance and Management, Vol. 12 No, 643-662.

Rama, A. (2013). Perbankan Syariah dan Pertumbuhan Ekonomi Indonesia. Jurnal Ilmu Ekonomi, 2 No.1. https://doi.org/10.15408/sjie.v2i1.2372

Roedyhantoro, T. (2018). Pengaruh Instrumen Moneter Konvensional dan Instrumen Moneter Syariah Terhadap Produk Domestik Bruto Periode 2012-2016. Jurnal Ekonomi Syariah Teori Dan Terapan, Vol. 5 No. 
Salina, R. \&. (2010). Peran Bank Syariah Dalam Proses Transmisi Moneter Di Malaysia. Jurnal Internasional Keuangan Dan Manajemen Islam Dan Timur Tengah, 3.

Setiawan, I. (2020). Analisis Peran Perbankan Terhadap Pertumbuhan Ekonomi di Indonesia: Bank Syariah Versus Bank Konvensional. Jurnal Akuntansi, Ekonomi Dan Manajemen Bisnis, 8 (1), 52-60.

Sexton M, A. H. (2006). Islam and Sustainable Development. Research Institute for Built and Human Environment University of Salford.

Titman, S \& Warga, A. (1989). Stock Return as Predictors of Interest Rates and Inflation. Journal of Financial and Quanittive Analysis, 24. https://doi.org/10.2307/2330747

Widyastuti, E., \& Arinta, Y. N. (2020). Perbankan Syariah dan Pertumbuhan Ekonomi Indonesia: Bagaimana Kontribusinya? Al-Muzara'ah, 8 (2), 129-140. https://doi.org/10.29244/jam.8.2

Y, S. (2019). Does Islam impede development? A critical analysis. Journal of Islamic Accounting and Business Research, Vol. 10 No, 644-662. 